\title{
Using lactic acid bacteria and packaging with grapefruit seed extract for controlling Listeria monocytogenes growth in fresh soft cheese
}

\author{
J. Y. Lim, (1) C. L. Lee, (i) G. H. Kim, (i) Y. J. Bang, (1) J. W. Rhim, (i) and K. S. Yoon* (i) \\ Department of Food and Nutrition, College of Human Ecology, Kyung Hee University, Seoul 02447, Republic of Korea
}

\begin{abstract}
Various cheese products are involved in outbreaks of listeriosis worldwide due to high consumption and prolonged refrigerated storage. The objective of this study was to determine the efficacy of using lactic acid bacteria and packaging with grapefruit seed extract (GSE) for controlling Listeria monocytogenes growth in soft cheese. Leuconostoc mesenteroides and Lactobacillus curvatus isolated from kimchi were used as a starter culture to make a soft cheese, which was inoculated with a cocktail strain of $L$. monocytogenes. The soft cheese was packed with low-density polyethylene, biodegradable polybutylene adipate-co-terephthalate (PBAT), low-density polyethylene with GSE, or PBAT with GSE and stored at $10^{\circ} \mathrm{C}$ and $15^{\circ} \mathrm{C}$. Leuconostoc mesenteroides $(\mathrm{LcM})$ better inhibited the growth of $L$. monocytogenes than Lb. curvatus. The PBAT with GSE film showed the best control for the growth of $L$. monocytogenes. When both LcM and PBAT with GSE were applied to the soft cheese, the growth of L. monocytogenes was inhibited significantly more than the use of LcM or PBAT with GSE alone. In all test groups, water activity, $\mathrm{pH}$, and moisture on a fat-free basis decreased, and titratable acidity increased compared with the control group. These results suggest that LcM isolated from kimchi and PBAT with GSE packaging film can be used as a hurdle technology to lower the risk of $L$. monocytogenes in soft cheese at the retail market.
\end{abstract}

Key words: Listeria monocytogenes, soft cheese, packaging, lactic acid bacteria

\section{INTRODUCTION}

Listeria monocytogenes is a psychotropic and salttolerant foodborne pathogen. The CDC (2016) has estimated that about 1,600 people get sick from Listeria and about 260 people die from it each year in

\footnotetext{
Received February 11, 2020.

Accepted May 13, 2020.

*Corresponding author: ksyoon@khu.ac.kr
}

the United States. Recently, an outbreak of Listeria infection has been linked to deli-sliced meats and cheese in the United States, leading to the hospitalization of 8 people and 1 death (CDC, 2019). The risk of L. monocytogenes in dairy products is based on its widespread occurrence in the environment of dairy plants and its ability to survive and grow on dairy products at refrigerated temperatures (Lourenço et al., 2017). Among dairy products, soft cheese is highly perishable with a limited shelf life even under refrigeration due to texture changes and bacteria growth (Di Pierro et al., 2011).

Bacteriocins of lactic acid bacteria (LAB) and grapefruit seed extract (GSE) are well documented to possess antimicrobial effects. During fermentation, $\mathrm{LAB}$ produce various compounds such as organic acids, diacetyl, hydrogen peroxide, and bacteriocins or bactericidal proteins (Lindgren and Dobrogosz, 1990). These components not only are desirable due to their effects on food flavor and texture, but also are needed to inhibit undesirable pathogenic organisms (Nettles and Barefoot, 1993).

Grapefruit seed extract is a natural antimicrobial and antioxidant agent that contains tocopherol, citric acid, ascorbic acid, and polyphenolic compounds such as catechins, epicatechin, epicatechin-3-O-gallate, and dimeric, trimeric, and tetrameric procyanidins (Cho et al., 1990; Saito et al., 1998). Grapefruit seed extract shows remarkable consistency in its action against a wide range of organisms including both gram-positive and gram-negative organisms (Reagor et al., 2002). It is generally recognized as safe without human toxicity (Xu et al., 2007). The bacterial growth inhibition effect of GSE can be ascribed to its polyphenols that can penetrate the semipermeable bacterial membrane to react with the cytoplasm or cellular proteins (Corrales et al., 2009). Heggers et al. (2002) have reported that all concentrations of GSE can cause cell death by disrupting the cell membrane of bacteria. The antimicrobial potential is higher because phenolic acids are present in the undissociated form rather than the dissociated form in GSE (Paulus, 2005).

Packaging materials with antibacterial properties could extend the shelf life of foods and reduce the risk 
of pathogens (Appendini and Hotchkiss, 2002). Previous studies have documented the antimicrobial activity of packaging film with GSE (Kanmani and Rhim, 2014; Sogut and Seydim, 2018). Various active food packaging technologies against foodborne pathogens were also reported. The desired antibacterial activity of chitosancoated, nisin-silica liposomes against L. monocytogenes was reported as a promising active packaging material (Cui et al., 2016). Also, improving the anti-Listeria activity of polyethylene oxide nanofiber containing nisinloaded nanoparticles was reported for cheese packaging without an effect on the sensory quality (Cui et al., 2017). Most recently, Lin et al. (2019) tested moringa oil-loaded chitosan nanoparticle for cheese packaging against L. monocytogenes and Staphylococcus aureus and recommended it for active food packaging materials in the food industry.

The present study aimed to evaluate the antimicrobial effect of LAB isolated from kimchi and packaging film containing GSE on L. monocytogenes growth in fresh soft cheese. The synergistic effect of LAB and packaging film with GSE was also tested against $L$. monocytogenes. We hypothesized that packaging films containing GSE could be used to extend the shelf life without causing a quality change of cheese. Thus, microbiological and physicochemical changes of cheese were also evaluated under the conditions of distribution temperature $\left(10^{\circ} \mathrm{C}\right)$ and temperature abuse $\left(15^{\circ} \mathrm{C}\right)$.

\section{MATERIALS AND METHODS}

\section{Preparation of Bacterial Strains}

Leuconostoc mesenteroides (LcM, KCTC 13374) and Lactobacillus curvatus (LbC, KCTC 3767) isolated from kimchi were used in this study as LAB. All LAB strains were purchased from the Korean Collection for Type Cultures (KCTC, Daejeon, Korea) and stored at $-80^{\circ} \mathrm{C}$ in deMan, Rogosa, and Sharpe (MRS) broth (MB cell, Seoul, Korea) containing 20\% glycerol. Each thawed strain $(10 \mu \mathrm{L})$ was then inoculated into $10 \mathrm{~mL}$ of MRS broth and incubated at $30^{\circ} \mathrm{C}$ overnight at 140 rpm on a rotary shaker. Appropriate dilutions were prepared to reach an inoculation level of 5.0 to $6.0 \mathrm{log}$ $\mathrm{cfu} / \mathrm{g}$ in fresh soft cheese samples.

Listeria monocytogenes strains (ATCC 15313, ATCC 19111) were purchased from the Korea Culture Center of Microorganisms (KCCM, Seoul, Korea). A strain of L. monocytogenes (serotype, 1/2a) isolated from smoked salmon was also used in this research. All strains of $L$. monocytogenes were maintained in tryptic soy broth (TSB; MB Cell, Seoul, Korea) supplemented with $0.6 \%$ yeast extract (Oxoid Ltd., Basingstoke, UK). All strains were stored at $-80^{\circ} \mathrm{C}$ in TSB containing $20 \%$ glycerol (Sigma-Aldrich, St. Louis, MO). Each strain of L. monocytogenes $(10 \mu \mathrm{L})$ was then thawed and inoculated into $10 \mathrm{~mL}$ of TSB supplemented with $0.6 \%$ yeast extract and incubated at $36^{\circ} \mathrm{C}$ overnight at 140 rpm on a rotary shaker (VS-8480SR, Vision, Daejeon, Korea). Appropriate dilutions of each strain were prepared to an inoculation level of $3.0 \mathrm{log} \mathrm{cfu} / \mathrm{g}$. An equal amount of each strain was mixed as a 3 -strain cocktail of L. monocytogenes for the inoculum onto soft cheese sample.

\section{Preparation of Antimicrobial Packaging Films}

Polyethylene was purchased from Freshield Inc. (Siheung, Korea). Low-density polyethylene (LDPE) was purchased from Hanwha Chemical Co. (Seoul, Korea). The LDPE resins were dried under vacuum at $60^{\circ} \mathrm{C}$ for $24 \mathrm{~h}$ before use. Polybutylene adipate-co-terephthalate (PBAT) was obtained from S-EnPol Co. Ltd. (Wonju, Korea). The PBAT resins were dried under vacuum at $90^{\circ} \mathrm{C}$ for $72 \mathrm{~h}$ before use. Corn starch was purchased from Daejung Chemicals and Metals Co. Ltd. (Siheung, Gyeonggi-do, Korea). Grapefruit seed extract (DF-100) was obtained from Komipharm International Co. Ltd. (Seoul, Korea). Thermoplasticized starch (TPC) was prepared as a carrier of the GSE by mixing corn starch with $20 \%$ of glycerol and $40 \%$ of GSE as a plasticizer and antimicrobial filler, respectively, at $250 \mathrm{rpm}$ for 10 min using a mixer (Ultra Power Series 4.5-quart stand mixer KSM90, KitchenAid, St. Joseph, MI). The mixture was heated at $120^{\circ} \mathrm{C}$ for 30 min using an autoclave, spread to cool to room temperature, and then powdered using a blender (DA700-G, Daesung Artion Co., Seoul, Korea) to obtain GSE-incorporated TPC.

The masterbatch for PBAT with GSE was prepared by mixing $5 \%$ GSE, $3 \%$ of zinc oxide nanoparticles, $8 \%$ of calcium stearate, and PBAT resins at $250 \mathrm{rpm}$ for 15 min using a low-speed mixer. Zinc oxide nanoparticles were prepared using the method described by Shankar and Rhim (2019). Briefly, 1,000 $\mathrm{mL}$ of $1 \mathrm{mM}$ zinc nitrate was heated to $70^{\circ} \mathrm{C}$. Then, $1 \mathrm{M} \mathrm{KOH}$ solution was added dropwise with vigorous stirring until the $\mathrm{pH}$ reached around 8 , followed by continued heating and stirring for $30 \mathrm{~min}$. White precipitates were centrifuged at $970 \times g$ for $15 \mathrm{~min}$ at ambient temperature and washed with distilled water 4 to 5 times, followed by washing with ethanol for 2 to 3 times, and drying in an oven at $150^{\circ} \mathrm{C}$ for $24 \mathrm{~h}$. The PBAT with GSE composite film was prepared with a thermocompression method using a Carver laboratory press (Hydraulic unit, model 3925, Carver Inc., Wabash, IN). About $4 \mathrm{~g}$ of the masterbatch was placed between 2 stainless steel plates (1 
mm thick, $\left.25.4 \times 25.4 \mathrm{~cm}^{2}\right)$ coated with Teflon sheets and then pressurized at about $60,000 \mathrm{psi}(414 \mathrm{MPa})$ at $130^{\circ} \mathrm{C}$ for $3 \mathrm{~min}$. The masterbatch for LDPE film with GSE was prepared by mixing TPC containing $3 \%$ GSE and LDPE resins with a weight ratio of 1:10 using a high-speed mixer (600 rpm) for $1 \mathrm{~h}$. For LDPE resin, $3 \%$ GSE was the maximum concentration to maintain the packaging film. The mixture was then extruded using a twin-screw extruder (YJC-ST- $\varnothing 48 / 34$, Yoojin Eng. Co. Ltd., Siheung, Korea) with a screw speed of $600 \mathrm{rpm}$. The LDPE-based blend films were prepared using an extrusion blowing method as described previously (Hong and Rhim, 2012). The LDPE masterbatch with TPC was extruded using a single-screw extruder (YJF-faØ50-800L, Yoojin Eng. Co. Ltd.) following the method described by Hong and Rhim (2012). Neat LDPE film was also prepared using the same procedure without TPC. The chemicals we used for packaging film were safe; the FDA proved them as generally recognized as safe, and PBAT is an eco-friendly biodegradable material.

\section{Preparation of Fresh Soft Cheese}

Fresh soft cheese samples were prepared with or without LAB according to a modified general cheese manufacturing method (Chandan et al., 2015). Pasteurized whole milk was purchased from a local market and heated to $37^{\circ} \mathrm{C}$ in a water bath (SB-1200, Eyela, Tokyo, Japan). We added LcM or LbC to milk as a starter culture at $10^{5}$ to $10^{6} \mathrm{cfu} / \mathrm{mL}$, mixed for $1 \mathrm{~min}$, and let ferment at $40^{\circ} \mathrm{C}$ for $1 \mathrm{~h}$. We added $0.02 \%$ of rennet (Maysa, Istanbul, Turkey) and $0.2 \%$ of citric acid (Weifang Ensign Industry Co. Ltd., Weifang, China) to coagulate the milk. After coagulation, samples were cut to separate the curd and whey. Cooled fresh soft cheese was then pressurized. Figure 1 shows the flowchart of fresh soft cheese manufacturing with processing treatments.

\section{Antimicrobial Effect of LAB and Packaging Film Containing GSE}

To determine the antimicrobial effects of LAB isolated from kimchi and packaging film containing GSE on L. monocytogenes in fresh soft cheese, 3 different treatment groups were prepared, as shown in Figure 1. For the LAB treatment group, soft cheese was prepared with $\mathrm{LcM}, \mathrm{LbC}$, or the mixture of $\mathrm{LcM}$ and $\mathrm{LbC}$ in a $7: 3$ ratio. We used this ratio because it was the most effective in inhibiting L. monocytogenes and Salmonella Typhimurium in dry fermented sausage in our previous work (our unpublished data). Soft cheese samples prepared with $\mathrm{LAB}$ were inoculated with $100 \mu \mathrm{L}$ of a 3 -strain cocktail of $L$. monocytogenes onto the surface of fresh soft cheese at a level of 2.5 to $3.5 \mathrm{log} \mathrm{cfu} / \mathrm{g}$ using an automatic pipette. Then, 4 films (LDPE, PBAT, LDPE with GSE, and PBAT with GSE) were used as the inner packaging film of soft cheese, which was then vacuum packed with polyethylene. For a synergistic effect of LAB and antimicrobial packaging film, a combination of LcM and PBAT with GSE was also tested. For comparison, a control group that received no treatment was included. They were stored at $10^{\circ} \mathrm{C}$ (distribution temperature) and $15^{\circ} \mathrm{C}$ (abused temperature), respectively.

\section{Quality Evaluation}

Microbiological analysis and physicochemical characteristics of soft cheese samples were measured at $10^{\circ} \mathrm{C}$ (distribution temperature) and $15^{\circ} \mathrm{C}$ (abuse temperature) on d $0,5,10,15,25$, and 30. Physicochemical characteristics including water activity (Aw), $\mathrm{pH}$, titratable acidity, moisture content, and fat were determined in fresh soft cheese samples according to AOAC International, (1995).

\section{Microbiological Analysis}

For bacteria enumeration during storage, fresh soft cheese $(10 \mathrm{~g}$ each) were aseptically transferred into sterile filter bags and homogenized in 40 to $90 \mathrm{~mL}$ of $0.1 \%$ (wt/vol) sterile peptone water for 2 min using a stomacher (Interscience, Paris, France). Subsequent decimal dilutions in peptone water were then plated onto MRS agar for LAB and incubated at $30^{\circ} \mathrm{C}$ for 48 $\mathrm{h}$ or plated onto PALCAM agar for L. monocytogenes and incubated at $37^{\circ} \mathrm{C}$ for $48 \mathrm{~h}$. Serial decimal dilutions of samples were plated in duplicate onto aerobic count plates and Escherichia coli (coliform) count plates (Petrifilm 3M, Seoul, Korea), respectively.

\section{Water Activity, pH Measurement and Titratable Acidity}

The Aw of cheese was measured with an Aw meter (AwTherm, Rotronic, NY). Measurement of $\mathrm{pH}$ was carried out (Orion 3-star pH-Benchtop, Thermo) by immersing a probe into $90 \mathrm{~mL}$ of distilled water containing $10 \mathrm{~g}$ of fresh soft cheese samples. Contents were constantly stirred until stable $\mathrm{pH}$ measurements were recorded.

To determine titratable acidity, $10 \mathrm{~g}$ of fresh soft cheese sample was homogenized with $90 \mathrm{~mL}$ of distilled water at $40^{\circ} \mathrm{C}$ using a stomacher (Stomacher, Inter- 


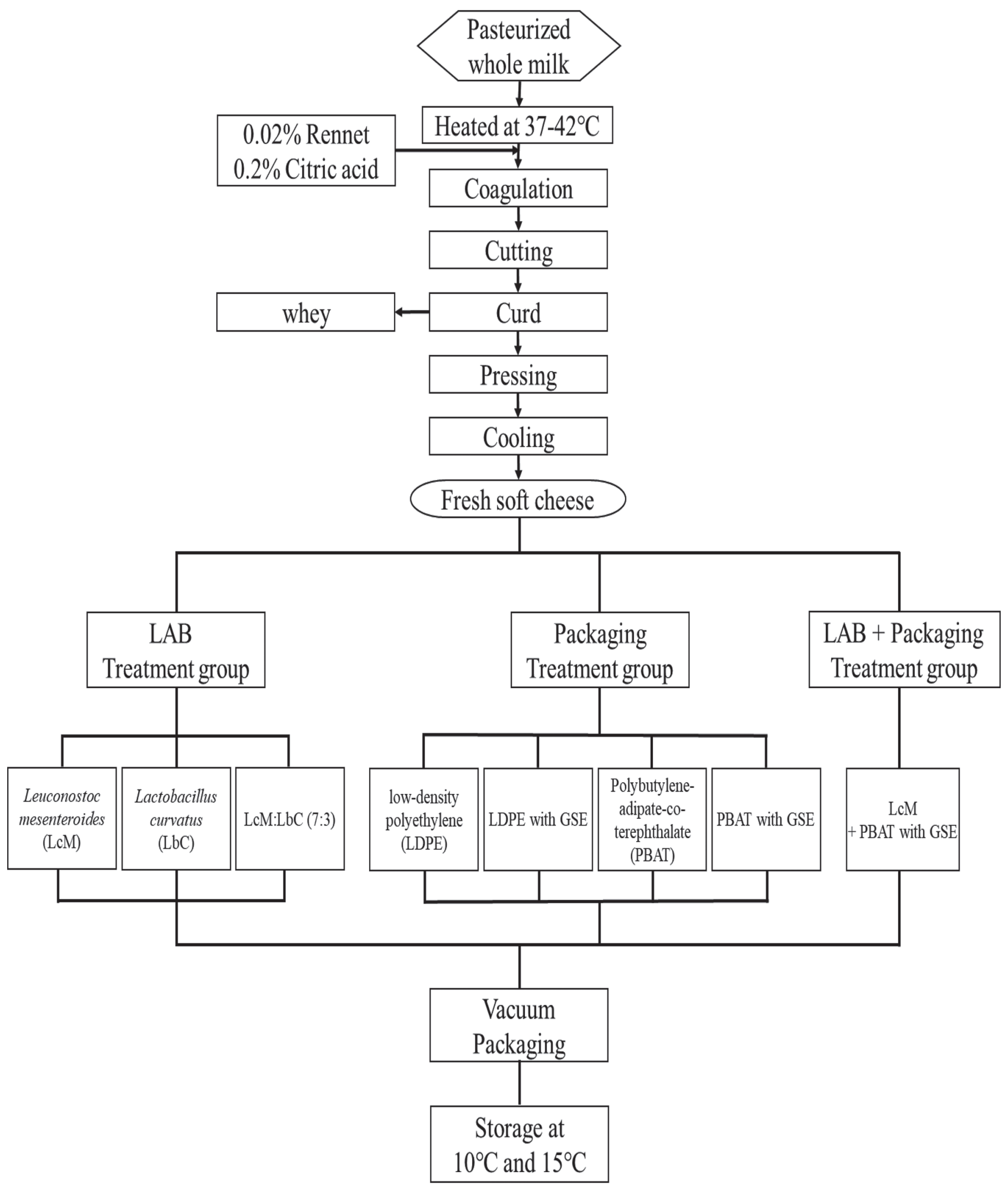

Figure 1. Manufacturing flowchart of fresh soft cheese and processing treatments. Lactic acid bacteria (LAB) was added before the coagulation process. GSE $=$ grapefruit seed extract. 
science, France) and filtrated. Filtrate $(25 \mathrm{~mL})$ was collected and titrated with $0.1 \mathrm{~N}$ standard $\mathrm{NaOH}$. Phenolphthalein was used as an indicator. The titratable acidity was expressed as lactic acid using the following formula:

$$
\begin{aligned}
& \text { Total titratable acidity }(\%)= \\
& \frac{0.1 N \mathrm{NaOH}(\mathrm{mL}) \times 0.1 N \mathrm{NaOH} \text { factor } \times 0.009}{\text { Sample }(\mathrm{g})} \times 100 .
\end{aligned}
$$

\section{Moisture, Fat, and Moisture on a Fat-Free Basis}

For moisture analysis, each 2 -g cheese sample was weighed in a 5 -cm diameter flat-bottomed metal dish. Each sample was placed in the oven at $100^{\circ} \mathrm{C}$ and dried to constant weight $(\sim 3 \mathrm{~h})$. The sample dish was removed from the oven, cooled, and weighed. Expressed loss in weight was calculated as moisture content using the following formula:

$$
\text { Moisture content }(\%)=100-\text { solid content }(\%) \text {. }
$$

For fat analysis, cheese sample (1 g) was weighed into a tall-form beaker. Then, $9 \mathrm{~mL}$ of $\mathrm{H}_{2} \mathrm{O}$ and $1 \mathrm{~mL}$ of $\mathrm{NH}_{4} \mathrm{OH}$ were added. The sample was mixed until smooth. It was then warmed at $40^{\circ} \mathrm{C}$ until casein was well softened. The sample was neutralized with 10 $\mathrm{mL}$ of $\mathrm{HCl}$ for $5 \mathrm{~min}$. The solution was cooled and transferred to a fat-extraction flask. The used tall-form beaker was rinsed out successively with $10 \mathrm{~mL}$ of alcohol, $25 \mathrm{~mL}$ of ether, and $25 \mathrm{~mL}$ of petroleum ether (boiling range: $30-60^{\circ} \mathrm{C}$ ), which was transferred to a fat-extraction flask and mixed thoroughly. It was let to stand until the upper liquid was practically transparent. The ether solution was decanted into another weighed flask. Lip and stopper of extraction flask were washed with a mixture of equal parts of ether and petroleum ether. Washings were then added to the weighing flask. Extraction was repeated twice using $15 \mathrm{~mL}$ of ethers each time. Solvents were evaporated completely on an evaporator (N-1200A, Eyela, Shanghai, China) at $50^{\circ} \mathrm{C}$. The fat was dried to constant weight in an oven at $100^{\circ} \mathrm{C}$. The cooled flask was weighed without wiping immediately before weighing.

Using the data (moisture content and fat in cheese) obtained above, moisture on a fat-free basis was calculated as follows:

\footnotetext{
Weight of moisture in the cheese

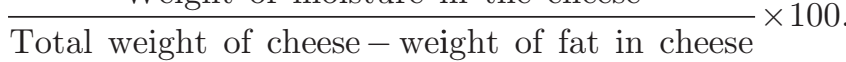

\section{Statistical Analysis}

Each experiment was repeated at least twice at different times, with 2 replicates per treatment. For each replication, at least 2 to 4 measurements of each parameter were performed. All statistical analyses were performed using SAS version 9.4 (SAS Institute Inc., Cary, NC). Because our data had a normal distribution with unequal variances, a significant difference among samples was determined by Welch's ANOVA, followed by Duncan's multiple range tests at $P<0.05$.

\section{RESULTS AND DISCUSSION}

\section{Antimicrobial Effect of LAB on L. Monocytogenes in Fresh Soft Cheese}

Antimicrobial effects of LcM, LbC, and the mixture of $\mathrm{LcM}$ and $\mathrm{LbC}$ on populations of L. monocytogenes in soft cheese at $10^{\circ} \mathrm{C}$ and $15^{\circ} \mathrm{C}$ are shown in Figure 2. At $10^{\circ} \mathrm{C}$, there was no significant $(P>0.05)$ difference in the lag time of L. monocytogenes between $\mathrm{LbC}$ and the control. However, LcM and the mixture of LcM and LbC (7:3) significantly $(P<0.05)$ extended the lag time up to 3.6 and 2.5 times, respectively. The maximum population density of $L$. monocytogenes in soft cheese containing LcM or the mixture of LcM and LbC was lowered to 23.1 or $25.9 \%$, respectively, compared with that of the control. At $15^{\circ} \mathrm{C}$, significant $(P<0.05)$ extension of lag time and lower of maximum population density were observed in all treatment groups compared with the control. However, the specific growth rate was not significantly $(P>0.05)$ affected by the addition of different types of LAB. Coelho et al. (2014) prepared fresh cheese from pasteurized cow's milk inoculated with bacteriocin-producing LAB and L. monocytogenes. They found that all LAB strains inhibited the growth of $L$. monocytogenes during storage at $4^{\circ} \mathrm{C}$ for up to 15 d. Aymerich et al., (2019) also reported that Lactobacillus sakei CTC494 inhibited the growth of L. monocytogenes in smoked salmon after $21 \mathrm{~d}$ of storage at $8^{\circ} \mathrm{C}$.

Several antimicrobial compounds produced by LAB have been identified and characterized individually for their inhibitory potential against spoilage organisms (Crowley et al., 2013). These compounds range from simple organic acids and primary metabolic products to very complex compounds derived from bioconversions or peptide synthesis, as well as protein cleavage. The most essential and best-characterized antimicrobials produced by LAB are lactic acid and acetic acid. They are bioactive in their protonated form at a low $\mathrm{pH}$ (Arena et al., 2016). 
$10^{\circ} \mathrm{C}$

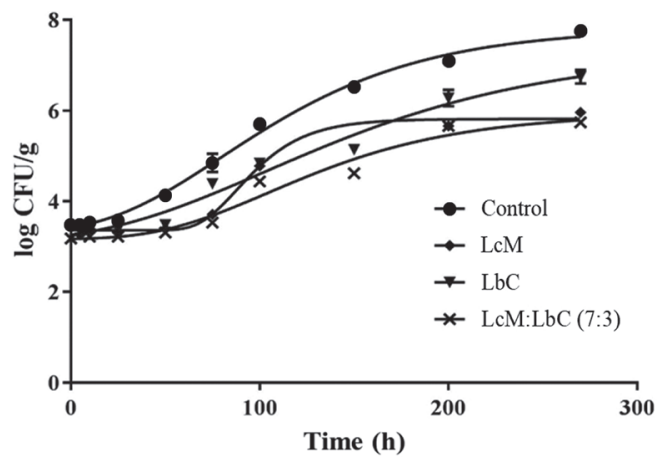

$15^{\circ} \mathrm{C}$

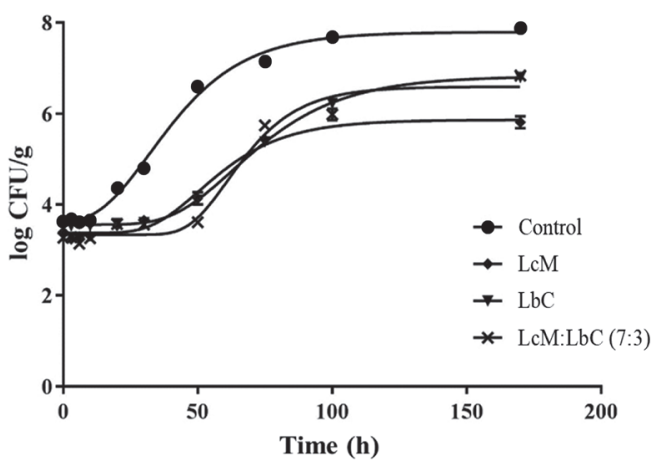

Figure 2. The effect of lactic acid bacteria on the growth of Listeria monocytogenes in fresh soft cheeses at 10 and $15^{\circ} \mathrm{C}$. Control $=$ Leuconostoc mesenteroides $(\mathrm{LcM})=\diamond$, Lactobacillus curvatus $(\mathrm{LbC})=\boldsymbol{\nabla}$, and the mixture of $\mathrm{LcM}$ and $\mathrm{LbC}$ at $7: 3$ ratio $=\times$.

\section{Antimicrobial Effect of Packaging Film with GSE on L. Monocytogenes in Fresh Soft Cheese}

Fresh soft cheese was prepared individually and packed with different packaging film: LDPE, LDPE containing 3\% GSE (LDPE with GSE), biodegradable PBAT, and PBAT containing 5\% GSE (PBAT with GSE). Overall, packaging films containing GSE had a better performance delaying the growth of $L$. monocytogenes in soft cheese than those without GSE (Table 1). At $10^{\circ} \mathrm{C}$, there was no significant difference in lag time, and maximum population density of L. monocytogenes in soft cheese between LDPE with GSE and PBAT with GSE groups, but the specific growth rate was well controlled in soft cheese packed with PBAT with GSE. On the other hand, the longest lag time was observed in soft cheese packed with PBAT with GSE at $15^{\circ} \mathrm{C}$. Wang and Rhim (2016) reported that the antibacterial activity of the packaging film was de- pendent on the type of polymer matrix, which affected the releasing rate of the GSE. If the polymer matrix more tightly entraps the GSE, the diffusion rate of the GSE from the film decreased, consequently resulting in lower antibacterial activity. The PBAT packaging is a biodegradable material with low water vapor permeability, high flexibility, and good processability (Witt et al., 2001). Poly(lactide)-PBAT-GSE composite film exhibited a high potential for an active food packaging application with antibacterial properties (Shankar and Rhim, 2018). A slightly better antimicrobial effect of PBAT with GSE than LDPE with GSE was observed in the present work. The antimicrobial effect of GSE against L. monocytogenes has also been reported in previous studies. Pork loin packed with the edible Gelidium corneum-gelatin blend film containing $0.08 \%$ GSE showed a decrease in populations of L. monocytogenes of 1.05 to $1.14 \mathrm{log} \mathrm{cfu} / \mathrm{g}$ compared with the control after $4 \mathrm{~d}$ of storage at $4^{\circ} \mathrm{C}$ (Hong et al., 2009).

Table 1. Effect of packaging on the kinetic parameters of Listeria monocytogenes in fresh soft cheese at $10^{\circ} \mathrm{C}$ and $15^{\circ} \mathrm{C}$

\begin{tabular}{|c|c|c|c|c|c|c|}
\hline \multirow[b]{2}{*}{ Treatment $^{1}$} & \multicolumn{3}{|c|}{$10^{\circ} \mathrm{C}$} & \multicolumn{3}{|c|}{$15^{\circ} \mathrm{C}$} \\
\hline & $\mathrm{LT}^{2}$ & $\mathrm{SGR}^{3}$ & $\mathrm{MPD}^{4}$ & $\mathrm{LT}$ & SGR & MPD \\
\hline Control & $18.74^{\mathrm{c}}$ & $0.03^{\mathrm{b}}$ & $7.75^{\mathrm{a}}$ & $12.86^{\mathrm{d}}$ & $0.08^{\mathrm{a}}$ & $7.87^{\mathrm{a}}$ \\
\hline LDPE & $34.44^{\mathrm{a}}$ & $0.04^{\mathrm{a}}$ & $7.51^{\mathrm{a}}$ & $25.64^{\mathrm{c}}$ & $0.07^{\mathrm{b}}$ & $7.39^{\mathrm{bc}}$ \\
\hline LDPE with GSE & $29.58^{\mathrm{bc}}$ & $0.03^{\mathrm{b}}$ & $6.89^{\mathrm{b}}$ & $27.12^{\mathrm{b}}$ & $0.05^{\mathrm{c}}$ & $7.43^{\mathrm{bc}}$ \\
\hline PBAT & $8.30^{\mathrm{d}}$ & $0.03^{\mathrm{b}}$ & $7.57^{\mathrm{a}}$ & $9.90^{\mathrm{e}}$ & $0.05^{\mathrm{c}}$ & $7.50^{\mathrm{b}}$ \\
\hline PBAT with GSE & $23.25^{\mathrm{bc}}$ & $0.02^{\mathrm{c}}$ & $6.76^{\mathrm{b}}$ & $34.92^{\mathrm{a}}$ & $0.07^{\mathrm{b}}$ & $7.27^{\mathrm{c}}$ \\
\hline
\end{tabular}

${ }^{\mathrm{a} e}$ Mean values $(\mathrm{n}=4)$ in the same column with different superscripts are significantly different $(P<0.05)$.

${ }^{1}$ Packaging treatments: LDPE = low-density polyethylene; LDPE with GSE = LDPE containing $3 \%$ grapefruit seed extract; $\mathrm{PBAT}=$ polybutylene adipate-co-terephthalate (biodegradable); PBAT with GSE $=$ PBAT containing $5 \%$ grapefruit seed extract.

${ }^{2} \mathrm{LT}=$ lag time $(\mathrm{h})$.

${ }^{3} \mathrm{SGR}=$ specific growth rate $(\log \mathrm{cfu} / \mathrm{h})$.

${ }^{4} \mathrm{MPD}=$ maximum population density $(\log \mathrm{cfu} / \mathrm{g})$. 
Red algae film containing 1\% GSE reduced populations of $L$. monocytogenes by $0.85 \mathrm{log} \mathrm{cfu} / \mathrm{g}$ in a cheese after $15 \mathrm{~d}$ of storage at $4^{\circ} \mathrm{C}$ (Shin et al., 2012).

\section{Antimicrobial Synergistic Effect of LAB and PBAT Film with GSE on L. Monocytogenes}

Soft cheese was made with LcM and packaged with PBAT with GSE to investigate the antimicrobial synergistic effect of LAB and packaging film. At both $10^{\circ} \mathrm{C}$ and $15^{\circ} \mathrm{C}$, the addition of LcM strain, PBAT with GSE packaging, or the combination of LcM with PBAT with GSE significantly affected lag time and maximum population density of L. monocytogenes (Figure 3 ). However, the specific growth rate of $L$. monocytogenes was the most affected by the addition of LcM or the combination of LcM with PBAT with GSE packaging. At both $10^{\circ} \mathrm{C}$ and $15^{\circ} \mathrm{C}$, significantly longer lag time and lower maximum population density of L. monocytogenes were observed in soft cheese made with LcM and packed with PBAT with GSE film compared with the control. This result indicated that the addition of LcM as a starter could be a key to control L. monocytogenes growth in soft cheese. The most effective antimicrobial effect against L. monocytogenes was observed in soft cheese made with LcM and packaged with PBAT with GSE in this work. Compared with the control, lag time values at $10^{\circ} \mathrm{C}$ and $15^{\circ} \mathrm{C}$ were extended to 1.7 and 3.6 times, respectively. Specific growth rate values at $10^{\circ} \mathrm{C}$ and $15^{\circ} \mathrm{C}$ also decreased by up to $66.7 \%$ and $75 \%$, respectively. The lowest maximum population density value was observed at both temperatures, indicating that the isolated LcM strain from kimchi can be used as a starter culture, along with PBAT with GSE film packaging to control L. monocytogenes in soft cheese. Furthermore, the group of soft cheese containing LcM and packed with PBAT with GSE had the lowest population of coliforms and total aerobic bacteria during 30 d of storage (data not shown).

Lactic acid bacteria can produce various antimicrobial compounds such as lactic acid, acetic acid, diacetyl, ethanol, hydrogen peroxide, reuterin, acetaldehyde, acetoin, carbon dioxide, and bacteriocins during fermentation processes. These natural compounds could be used as biopreservatives to inhibit pathogenic, nonpathogenic, and spoilage microorganisms, thus extending the shelf life of products and reducing the use of antibiotics (Özogul and Hamed, 2018). Abedi et al. (2013) tested the antibacterial effect of Lactobacillus delbrueckii ssp. bulgaricus on E. coli using disk diffusion and spot-on-lawn methods. The inhibition zone of $E$. coli by L. delbrueckii was $21.1 \mathrm{~mm}$ with the spot-onlawn method. It was $9.1 \mathrm{~mm}$ with the disk diffusion method. The LAB isolated from kimchi inhibited not only the growth of Salmonella Typhimurium and $L$. monocytogenes (our unpublished data), but also the growth of pathogenic E. coli (Choi et al., 2018).

\section{Hurdle Effect of LAB and PBAT Film with GSE on Microbiological and Physicochemical Changes of Soft Cheese During Storage at $10^{\circ} \mathrm{C}$}

Water activity is one of the most important physicochemical parameters. It is beneficial for controlling the ripening process for the final organoleptic properties and safety standards of cheese (Saurel et al., 2004). The initial Aw of soft cheese is usually 0.96 to 1.00 (Marcos and Esteban, 1982). As shown in Figure 4, the Aw of the fresh soft cheese was significantly $(P<0.05)$ higher in the PBAT with GSE group over the storage period at $10^{\circ} \mathrm{C}$. The $\mathrm{Aw}$ values of $\mathrm{LcM}$ and $\mathrm{LcM}$ with PBAT with GSE groups decreased from 0.979 to 0.951
$10{ }^{\circ} \mathrm{C}$

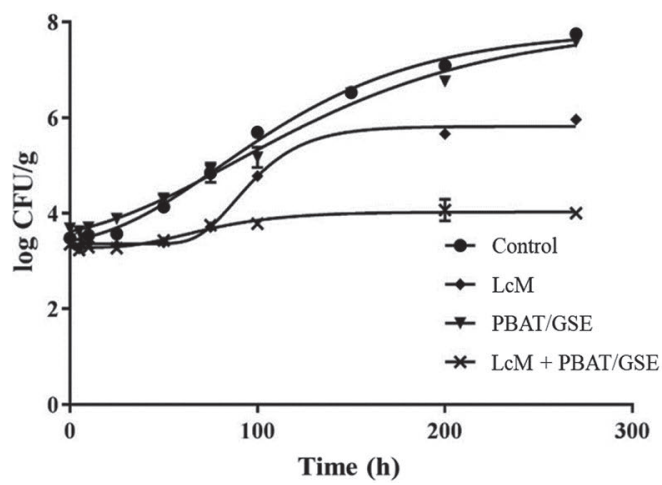

$15^{\circ} \mathrm{C}$

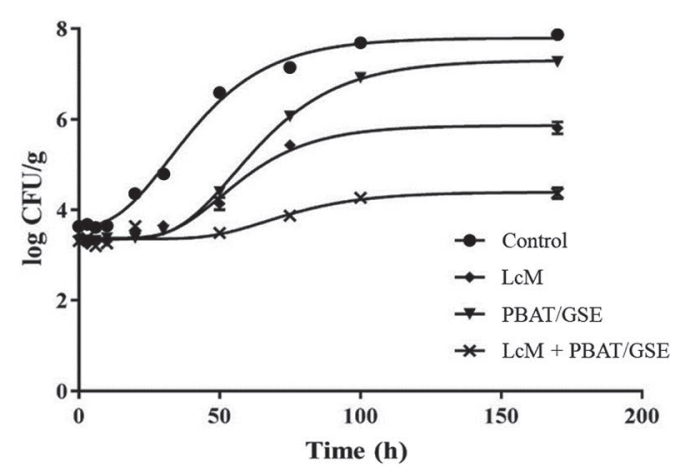

Figure 3. The effect of lactic acid bacteria and packaging on the growth of Listeria monocytogenes in fresh soft cheeses at 10 and $15^{\circ} \mathrm{C}$. Control $=\bullet$, Leuconostoc mesenteroides $(\mathrm{LcM})=\bullet$, biodegradable polybutylene adipate-co-terephthalate (PBAT) with $5 \%$ grapefruit seed extract $(\mathrm{GSE})=\mathbf{\nabla}$, both LcM and PBAT with GSE $=\times$. 

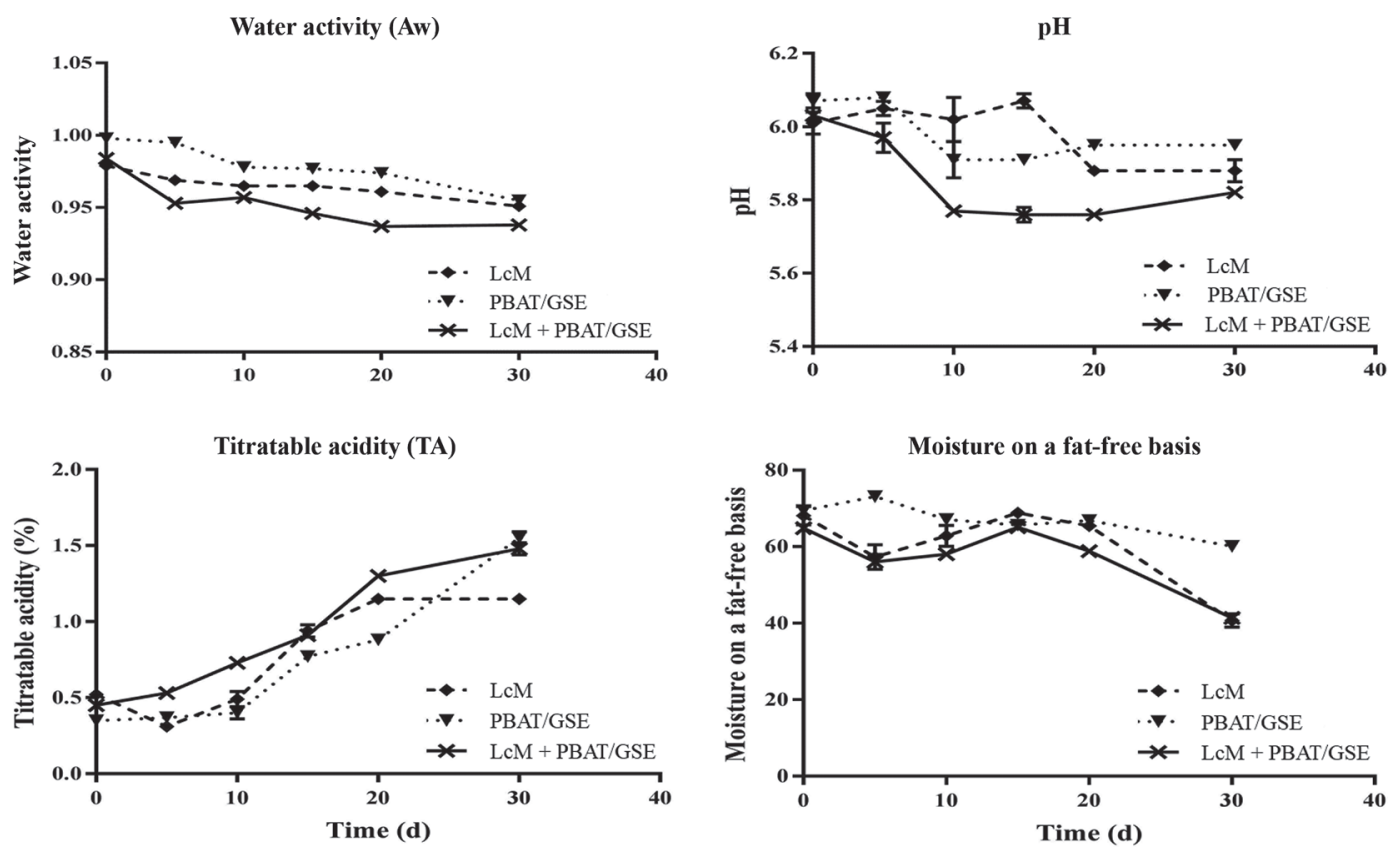

Figure 4. Comparison of microbiological and physicochemical changes of fresh soft cheese with different treatments during storage at $10^{\circ} \mathrm{C}$. Leuconostoc mesenteroides $(\mathrm{LcM})=\diamond$, biodegradable polybutylene adipate-co-terephthalate $(\mathrm{PBAT})$ with $5 \%$ grapefruit seed extract $(\mathrm{GSE})=$ $\boldsymbol{\nabla}$, both LcM and PBAT with GSE $=\times$.

and from 0.984 to 0.938 , respectively. In general, $\mathrm{pH}$ values of the soft cheese gradually decreased regardless of treatment due to lactic acid formation in cheese. Whitley et al. (2000) reported a positive correlation of $\mathrm{pH}$ values with the increase of LAB.

The titratable acidity is important in the cheesemaking process because it plays a fundamental role in all phases of milk coagulation, including the aggregation of para-casein micelles and the reactivity of rennet. The titratable acidity also influences the rate of syneresis and determines the suitability of milk for cheese making (De Marchi et al., 2009). In the production of premium cheeses, milk with low acidity (hypoacidic milk) is generally considered unsuitable for cheese making because of its adverse effects on the rheology of acid-rennet curd and textural properties of cheese paste (Formaggioni et al., 2001). At $10^{\circ} \mathrm{C}$, initial titratable acidity values were 0.35 to $0.52 \%$, and final titratable acidity values in LcM, PBAT with GSE, and LcM with PBAT with GSE increased up to 1.15, 1.55, and $1.48 \%$, respectively, after $30 \mathrm{~d}$. These results were related to the decrease in the $\mathrm{pH}$ of soft cheese due to increased LAB populations during $30 \mathrm{~d}$ of storage. Previous studies have also shown that titratable acidity values of Ricotta cheese and Minas fresh cheese increased with increasing days of storage (Buriti et al., 2005).

Cheese moisture and fat content are generally 29.2 to $79.0 \%$ and 4.4 to $34.9 \%$, respectively (Chandan et al., 2009). Mozzarella cheese, as a soft cheese, has a
$54.1 \%$ moisture and a $21.6 \%$ fat content (Chandan et al., 2009). Based on the Korean industry standards, soft cheese has $>67 \%$ moisture on a fat-free basis. In this study, moisture, fat content, and moisture on a fatfree basis in fresh soft cheese was 52.9 to $56.4 \%, 14.2$ to $18.7 \%$, and 64.9 to $69.4 \%$, respectively. Moisture contents in LcM, PBAT with GSE, and LcM with PBAT with GSE groups decreased from 56.3, 56.4, and 52.9\% to $43.5,47.9$, and $44.2 \%$, respectively. During $30 \mathrm{~d}$ of storage at $10^{\circ} \mathrm{C}$, there was no significant difference in moisture content in PBAT with GSE group for up to 15 d, which seemed to be capable of keeping the moisture well, and moisture on the fat-free basis was maintained in LcM and LcM with PBAT with GSE groups up to $20 \mathrm{~d}$. This tendency was also observed at $15^{\circ} \mathrm{C}$ (data not shown).

\section{CONCLUSIONS}

The risk of L. monocytogenes in various cheese is based on its ability to grow on these products at refrigerated temperatures. In this work, we investigated the antimicrobial effects of $\mathrm{LcM}$ and $\mathrm{LbC}$ isolated from kimchi and packaging film containing GSE on $L$. monocytogenes in soft cheese. Addition of LcM and the mixture of LcM and LbC $(7: 3)$ significantly $(P<0.05)$ extended the lag time value. Significantly lower maximum population density and longer lag time values of L. monocytogenes were observed in soft cheese packed 
with LDPE or PBAT containing GSE. Notably, the lag time of L. monocytogenes in soft cheese packed with PBAT with GSE was 2.7 times longer than that of the control, even at the abused temperature $\left(15^{\circ} \mathrm{C}\right)$. The PBAT with GSE group was capable of keeping the moisture well at $10^{\circ} \mathrm{C}$ and $15^{\circ} \mathrm{C}$. The most effective antimicrobial effect was observed in soft cheese made with LcM and packaged with PBAT with GSE film. The results indicated that cheese manufacturing plants might be able to use this approach as a form of hurdle technology to control the growth of L. monocytogenes at the retail market.

\section{ACKNOWLEDGMENTS}

This research was supported by a grant (18162MFDS524) from the Ministry of Food and Drug Safety (Osong-eup, Korea) in 2018. The authors have not stated any conflicts of interest.

\section{REFERENCES}

Abedi, D., S. Feizizadeh, V. Akbari, and A. Jafarian-Dehkordi. 2013. In vitro anti-bacterial and anti-adherence effects of Lactobacillus delbrueckii subsp bulgaricus on Escherichia coli. Res. Pharm. Sci. $8: 260-268$.

AOAC International. 1995. Official Methods of Analysis, 16th ed. AOAC International, Arlington, VA.

Appendini, P., and J. H. Hotchkiss. 2002. Review of antimicrobial food packaging. Innov. Food Sci. Emerg. Technol. 3:113-126. https:// doi.org/10.1016/S1466-8564(02)00012-7.

Arena, M. P., A. Silvain, G. Normanno, F. Grieco, D. Drider, G. Spano, and D. Fiocco. 2016. Use of Lactobacillus plantarum strains as a bio-control strategy against food-borne pathogenic microorganisms. Front. Microbiol. 7:464. https://doi.org/10.3389/fmicb .2016.00464.

Aymerich, T., M. Rodríguez, M. Garriga, and S. Bover-Cid. 2019. Assessment of the bioprotective potential of lactic acid bacteria against Listeria monocytogenes on vacuum-packed cold-smoked salmon stored at $8^{\circ} \mathrm{C}$. Food Microbiol. 83:64-70. https://doi.org/ 10.1016/j.fm.2019.04.011.

Buriti, F. C., J. S. Da Rocha, and S. M. Saad. 2005. Incorporation of Lactobacillus acidophilus in Minas fresh cheese and its implications for textural and sensorial properties during storage. Int. Dairy J. 15:1279-1288. https://doi.org/10.1016/j.idairyj.2004.12.011.

CDC (Centers for Disease Control and Prevention). 2016. People at Risk. Accessed Mar. 4, 2019. http://www.cdc.gov/listeria/risk .html.

CDC (Centers for Disease Control and Prevention). 2019. Outbreak of Listeria Infections Linked to Deli-Sliced Meats and Cheese. Accessed Feb. 20, 2019. http://www.cdc.gov/listeria/outbreaks/ deliproducts-04-19/index.html.

Chandan, R. C., A. Kilara, and N. P. Shah. 2009. Cheese. Pages 273 308 in Dairy Processing and Quality Assurance. Wiley-Blackwell, Hoboken, NJ.

Chandan, R. C., A. Kilara, and N. P. Shah. 2015. Cheese. Pages 287309 in Dairy Processing and Quality Assurance. 2nd ed. John Wiley \& Sons, Hoboken, NJ.

Cho, S. H., I. W. Seo, J. D. Choi, and I. S. Joo. 1990. Antimicrobial and antioxidant activity of grapefruit and seed extract on fishery products. Korean. Su Ürün. Derg. 23:289-296.

Choi, Y., S. Lee, H. J. Kim, H. Lee, S. Kim, J. Lee, J. Ha, H. Oh, K.-H. Choi, and Y. Yoon . 2018. Pathogenic Escherichia coli and
Salmonella can survive in kimchi during fermentation. J. Food Prot. 81:942-946. https://doi.org/10.4315/0362-028X.JFP-17-459.

Coelho, M. C., C. C. G. Silva, S. C. Ribeiro, M. L. N. E. Dapkevicius, and H. J. D. Rosa. 2014. Control of Listeria monocytogenes in fresh cheese using protective lactic acid bacteria. Int. J. Food Microbiol. 191:53-59. https://doi.org/10.1016/j.ijfoodmicro.2014.08.029.

Corrales, M., J. H. Han, and B. Tauscher. 2009. Antimicrobial properties of grape seed extracts and their effectiveness after incorporation into pea starch films. Int. J. Food Sci. Technol. 44:425-433. https://doi.org/10.1111/j.1365-2621.2008.01790.x.

Crowley, S., J. Mahony, and D. van Sinderen. 2013. Current perspectives on antifungal lactic acid bacteria as natural bio-preservatives. Trends Food Sci. Technol. 33:93-109. https://doi.org/10.1016/j .tifs.2013.07.004.

Cui, H. Y., J. Wu, C. Li, and L. Lin. 2016. Anti-listeria effects of chitosan-coated nisin-silica liposome on Cheddar cheese. J. Dairy Sci. 99:8598-8606. https://doi.org/10.3168/jds.2016-11658.

Cui, H., J. Wu, C. Li, and L. Lin. 2017. Improving anti-listeria activity of cheese packaging via nanofiber containing nisin-loaded nanoparticles. Lebensm. Wiss. Technol. 81:233-242. https://doi.org/10 .1016/j.lwt.2017.04.003.

De Marchi, M., C. C. Fagan, C. P. O'donnell, A. Cecchinato, R. Dal Zotto, M. Cassandro, M. Penasa, and G. Bittante. 2009. Prediction of coagulation properties, titratable acidity, and $\mathrm{pH}$ of bovine milk using mid-infrared spectroscopy. J. Dairy Sci. 92:423-432. https://doi.org/10.3168/jds.2008-1163.

Di Pierro, P., A. Sorrentino, L. Mariniello, C. V. L. Giosafatto, and R. Porta. 2011. Chitosan/whey protein film as active coating to extend Ricotta cheese shelf-life. Lebensm. Wiss. Technol. 44:23242327. https://doi.org/10.1016/j.lwt.2010.11.031.

Formaggioni, P., M. Malacarne, A. Summer, E. Fossa, and P. Mariani. 2001. Milk with abnormal acidity. VI. The role of phosphorus content and the rennet-coagulation properties of Italian Friesian herd milks. Ann. Fac. Med. Vet. Univ. Parma 21:261-268.

Heggers, J. P., J. Cottingham, J. Gusman, L. Reagor, L. McCoy, E. Carino, R. Cox, and J. G. Zhao. 2002. The effectiveness of processed grapefruit-seed extract as an antibacterial agent: II. Mechanism of action and in vitro toxicity. J. Altern. Complement. Med. 8:333-340. https://doi.org/10.1089/10755530260128023.

Hong, S. I., and J. W. Rhim. 2012. Preparation and properties of melt-intercalated linear low density polyethylene/clay nanocomposite films prepared by blow extrusion. Lebensm. Wiss. Technol. 48:43-51. https://doi.org/10.1016/j.lwt.2012.03.009.

Hong, Y. H., G. O. Lim, and K. B. Song. 2009. Physical properties of Gelidium corneum-gelatin blend films containing grapefruit seed extract or green tea extract and its application in the packaging of pork loins. J. Food Sci. 74:C6-C10. https://doi.org/10.1111/j.1750 $-3841.2008 .00987 . x$.

Kanmani, P., and J. W. Rhim. 2014. Antimicrobial and physical-mechanical properties of agar-based films incorporated with grapefruit seed extract. Carbohydr. Polym. 102:708-716. https://doi .org/10.1016/j.carbpol.2013.10.099.

Lin, L., Y. Gu, and H. Cui. 2019. Moringa oil/chitosan nanoparticles embedded gelatin nanofibers for food packaging against Listeria monocytogenes and Staphylococcus aureus on cheese. Food Packag. Shelf Life 19:86-93. https://doi.org/10.1016/j.fpsl.2018.12.005.

Lindgren, S. E., and W. J. Dobrogosz. 1990. Antagonistic activities of lactic acid bacteria in food and feed fermentations. FEMS Microbiol. Rev. 7:149-163. https://doi.org/10.1111/j.1574-6968.1990 .tb04885.x.

Lourenço, A., M. B. Kamnetz, C. Gadotti, and F. Diez-Gonzalez. 2017. Antimicrobial treatments to control Listeria monocytogenes in queso fresco. Food Microbiol. 64:47-55. https://doi.org/10 $.1016 / \mathrm{j} \cdot \mathrm{fm} .2016 .12 .014$.

Marcos, A., and M. A. Esteban. 1982. Nomograph for predicting water activity of soft cheese. J. Dairy Sci. 65:1795-1797. https://doi.org/ 10.3168/jds.S0022-0302(82)82418-1.

Nettles, C. G., and S. F. Barefoot. 1993. Biochemical and genetic characteristics of bacteriocins of food-associated lactic acid bacteria. J. Food Prot. 56:338-356. https://doi.org/10.4315/0362-028X -56.4 .338 . 
Özogul, F., and I. Hamed. 2018. The importance of lactic acid bacteria for the prevention of bacterial growth and their biogenic amines formation: A review. Crit. Rev. Food Sci. Nutr. 58:1660-1670. https://doi.org/10.1080/10408398.2016.1277972.

Paulus, W. 2005. Microbicide data. Pages 534-608 in Directory of Microbicides for the Protection of Materials: A Handbook. Springer Science and Business Media, Berlin, Germany.

Reagor, L., J. Gusman, L. McCoy, E. Carino, and J. P. Heggers. 2002. The effectiveness of processed grapefruit-seed extract as an antibacterial agent: I. An in vitro agar assay. J. Altern. Complement. Med. 8:325-332. https://doi.org/10.1089/10755530260128014.

Saito, M., H. Hosoyama, T. Ariga, S. Kataoka, and N. Yamaji. 1998. Antiulcer activity of grape seed extract and procyanidins. J. Agric. Food Chem. 46:1460-1464. https://doi.org/10.1021/jf9709156.

Saurel, R., A. Pajonk, and J. Andrieu. 2004. Modeling of French Emmental cheese water activity during salting and ripening periods. J. Food Eng. 63:163-170. https://doi.org/10.1016/S0260 -8774(03)00295-4.

Shankar, S., and J. W. Rhim. 2018. Preparation of antibacterial poly(lactide)/poly(butylene adipate-co-terephthalate) composite films incorporated with grapefruit seed extract. Int. J. Biol. Macromol. 120:846-852. https://doi.org/10.1016/j.ijbiomac.2018.09 .004 .

Shankar, S., and J. W. Rhim. 2019. Effect of Zn salts and hydrolyzing agents on the morphology and antibacterial activity of zinc oxide nanoparticles. Environ. Chem. Lett. 17:1105-1109. https:// doi.org/10.1007/s10311-018-00835-Z.

Shin, Y. J., H. Y. Song, Y. B. Seo, and K. B. Song. 2012. Preparation of red algae film containing grapefruit seed extract and application for the packaging of cheese and bacon. Food Sci. Biotechnol. 21:225-231. https://doi.org/10.1007/s10068-012-0029-x.

Sogut, E., and A. C. Seydim. 2018. Development of chitosan and polycaprolactone based active bilayer films enhanced with nanocel- lulose and grape seed extract. Carbohydr. Polym. 195:180-188. https://doi.org/10.1016/j.carbpol.2018.04.071.

Wang, L. F., and J. W. Rhim. 2016. Grapefruit seed extract incorporated antimicrobial LDPE and PLA films: Effect of type of polymer matrix. Lebensm. Wiss. Technol. 74:338-345. https://doi.org/ 10.1016/j.lwt.2016.07.066.

Whitley, E., D. Muir, and W. M. Waites. 2000. The growth of Listeria monocytogenes in cheese packed under a modified atmosphere. J. Appl. Microbiol. 88:52-57. https://doi.org/10.1046/j.1365-2672 2000.00859.x.

Witt, U., T. Einig, M. Yamamoto, I. Kleeberg, W.-D. Deckwer, and R.-J. Müller. 2001. Biodegradation of aliphatic-aromatic copolyesters: Evaluation of the final biodegradability and ecotoxicological impact of degradation intermediates. Chemosphere 44:289-299. https://doi.org/10.1016/S0045-6535(00)00162-4.

Xu, W. T., K. L. Huang, F. Guo, W. Qu, J. J. Yang, Z. H. Liang, and Y. B. Luo. 2007. Postharvest grapefruit seed extract and chitosan treatments of table grapes to control Botrytis cinerea. Postharvest Biol. Technol. 46:86-94. https://doi.org/10.1016/j.postharvbio .2007.03.019.

\section{ORCIDS}

J. Y. Lim ๑ https://orcid.org/0000-0002-1704-3715

C. L. Lee (ㄴ) https://orcid.org/0000-0002-0136-4012

G. H. Kim ๑ https://orcid.org/0000-0003-3948-6469

Y. J. Bang (ㅇ https://orcid.org/0000-0001-5851-4248

J. W. Rhim ๑ https://orcid.org/0000-0003-1787-5391

K. S. Yoon ๑ https://orcid.org/0000-0002-7492-4076 